\title{
How Well do General-Skills ESL Textbooks Address Pronunciation?
}

\author{
Tracey M. Derwing, Lori G. Diepenbroek, \\ and Jennifer A. Foote
}

Many instructors are reluctant to teach pronunciation in adult ESL classrooms, often because of lack of formal training. However, significant numbers of ESL students want pronunciation instruction. Although stand-alone pronunciation courses for second-language (L2) learners exist, many students cannot gain access to them. One approach to meeting the needs of both instructors and students is for general-skills L2 textbooks to include pronunciation activities. We examined 12 ESL general-skills textbook series (48 texts in total) and six accompanying teachers' manuals to determine to what extent these popular books include pronunciation activities and how consistent the texts are across individual series. We also recorded which aspects of L2 pronunciation are the focus of the lessons. Task types were examined in a subset of five series. We found striking variability in the concentration of pronunciation activities both across and within series. Similarly, whereas some textbooks used several task types, others relied heavily on a limited range. Furthermore, some texts offered little in terms of explicit explanations. In some instances teachers' manuals provided instructors with guidance; others included little more than repeated admonitions to remind the students to monitor their L2 pronunciation. The implications for teachers of general ESL courses are discussed.

Plusieurs enseignants hésitent à enseigner la prononciation aux adultes dans les cours d'ALS, souvent parce qu'ils manquent de formation formelle. Toutefois, un nombre considérable d'apprenants en ALS voudraient qu'on enseigne la prononciation. Même si les cours autonomes de prononciation pour les apprenants d'une langue seconde existent, plusieurs étudiants n'y ont pas accès. Une démarche qui répondrait tant aux besoins des enseignants que ceux des étudiants consisterait à intégrer des activités de prononciation dans les manuels L2 évoquant des compétences générales. Nous avons examiné 12 séries de manuels de compétences générales en ALS (48 volumes en tout) et six manuels pour enseignants dans le but de déterminer dans quelle mesure ces manuels bien répandus Incluent des activités de prononciation et pour évaluer la cohérence interne de chaque série. Nous avons également noté quels aspects de la prononciation en langue seconde on évoquait dans les leçons. Dans un sous-ensemble de cinq séries, nous avons porté notre attention sur les types de tâches présentées. Nous avons trouvé une variabilité frappante dans les activités de prononciation, tant au sein d'une même

série que d'une série à l'autre. De même, alors que certains manuels présentent 
plusieurs types de tâches, d'autres en offrent qu'une gamme limitée. De plus, certains manuels incluent peu d'explications explicites. Dans certains cas, les manuels pour enseignants offraient un certain encadrement; d'autres se contentaient d'adresser des admonitions aux enseignants pour qu'ils rappellent aux étudiants de surveiller leur prononciation en langue seconde. Nous discutons des retombées pour les enseignants de cours généraux d'ALS.

For several years, researchers and practitioners have argued for more attention to pronunciation in second-language (L2) classrooms (Couper, 2006; Isaacs, 2009). There is also evidence that many English-as-a-second-language (ESL) students would like more opportunities to improve their pronunciation (Derwing \& Rossiter, 2002; Foote, Holtby, \& Derwing, 2011). This is not surprising given that L2 speakers who have a strong mastery of other aspects of Englishlanguage proficiency but who still have pronunciation difficulties may have limited career advancement opportunities and lower earnings (Davila, Bohara, \& Saenz, 1993; Pendakur \& Pendakur, 1997; Reitz \& Sklar, 1997).

Although the demand for ESL pronunciation instruction has been partly addressed in that several pronunciation textbooks and teacher resources are currently available (Celce-Murcia et al., 2010; Gilbert, 2004; Grant, 2010; Hewings, 2004; Yates \& Zielinski, 2009), many students are unable to access stand-alone courses (Foote et al.). For these learners, the general-skills ESL classroom may be the only place to receive explicit instruction and feedback related to pronunciation. Thus general-skills language textbooks may play an important role in determining whether learners are exposed to useful pronunciation activities. For this reason, we have analyzed the nature and extent of pronunciation activities in popular ESL general-skills textbooks to determine to what degree pronunciation is included and which aspects of pronunciation receive the most attention. We have restricted our investigation to textbooks and teachers' manuals, although many of the series examined also include CDs with listening activities (not necessarily intended for pronunciation). In our experience, ESL programs' and instructors' use of CDs and DVDs in the classroom varies extensively, and we argue that the use of CDs will be reflected in the number and range of pronunciation activities in the textbooks themselves. However, programs that require learners to buy textbooks are likely to use these books regularly. In fact, in a survey of pronunciation teaching practices in Canada, $60.2 \%$ of instructors indicated that they used the pronunciation activities in their general-skills textbooks, whereas only $18.3 \%$ reported not doing so. The remaining $21.5 \%$ said that their textbooks had no pronunciation activities (Foote et al.).

To understand L2 pronunciation, it is helpful to consider three partly related constructs: intelligibility, comprehensibility, and accent. Intelligibility, whether an utterance is understood by an interlocutor, is the most important 
of the three. Intelligibility is often measured by having listeners transcribe utterances (Munro \& Derwing, 1995a). Comprehensibility is a listener's perception of how easy or difficult second-language speech is to understand. Although closely aligned to intelligibility, comprehensibility is partly independent because intelligibility can be relatively high even when comprehensibility is judged to be somewhat lower. Finally, accent is how different the phonology of an individual's speech is from that of the listener (Derwing, Munro, \& Wiebe, 1998). Although raters will almost always judge unintelligible L2 speech as both incomprehensible and highly accented, the reverse is not necessarily true (Munro \& Derwing, 1995a). That is, raters will assess some individuals with strong accents as easy to understand and will find some heavily accented speech fully intelligible.

Most researchers agree that intelligibility and comprehensibility should be the primary goals of pronunciation instruction, not the eradication of accent (Derwing \& Munro, 2005; Isaacs, 2008; Kennedy \& Trofimovich, 2008; Levis, 2005). In recent years, investigations have been conducted to assess how various aspects of pronunciation make contributions to intelligibility. For example, prosodic features play an important role in both accent ratings and intelligibility scores (Anderson-Hsieh, Johnson, \& Koehler, 1992; Munro \& Derwing, 1995a). More specifically, primary sentence stress (Hahn, 2004), word stress (Field, 2005; Zielinski, 2008) and speaking rate (Munro \& Derwing, 2001) affect intelligibility. As for segments, some consonants and vowels have more importance or a higher functional load than others (Catford, 1987; Munro \& Derwing, 2006) and are thus more critical to comprehensibility.

Instruction in pronunciation of L2 has also been the focus of research studies. Derwing et al., (1998) undertook before-and-after tests of students enrolled in a 12-week course that concentrated on prosodic (or suprasegmental) factors. In a listening experiment in which pre- and post-course speech samples were assessed for intelligibility, comprehensibility, and accentedness, the instruction resulted in significant improvements on all three measures. Derwing et al. later compared two approaches to pronunciation instruction. For 12 weeks, one group received segmental training, one group received suprasegmental training, and a third group received no pronunciation instruction. Both instructed groups made significant improvements in comprehensibility when assessed using a controlled speaking task, but only the suprasegmental group demonstrated significant improvement in an extemporaneous speaking task.

Couper (2003) taught an intermediate-level ESL course, dedicating two hours weekly to segmentals and suprasegmentals. The classroom tasks included analysis and explanations of pronunciation features, controlled practice, listen-and-repeat activities, and the use of recorders. Progress was measured using pre- and post-tests and indicated that the learners made sig- 
nificant improvements over 16 weeks. Couper (2006) later demonstrated that with targeted instruction, learners made significant improvements in reducing epenthesis and consonant deletion.

In a study investigating the teaching of $/ 1 /$ and $/ \lambda /$ to Japanese learners of English, Saito and Lyster (2012) examined the role of corrective feedback (CF). Two treatment groups and one control group participated in four hours of training. One group received form-focused instruction (FFI) without $\mathrm{CF}$, another received FFI with $\mathrm{CF}$ (recasts), and another received instruction unrelated to $/ \lambda /$. Only the group that received CF showed significant improvement.

Each of these classroom studies indicated that pronunciation instruction could make a difference. However, many ESL/EFL instructors may be unaware of the findings of current pronunciation research (Derwing \& Munro, 2005). Moreover, in a survey of Canadian ESL instructors, Foote et al. (2011) found that fewer than half the respondents had taken a course with a focus on how to teach L2 pronunciation. Burns (2006) surveyed ESL instructors who taught in the Australian Adult Migrant English Program and found that that many instructors desired more professional development and "were unsure, in particular, about teaching suprasegmental features" (p. 35). This view was also expressed in a survey of ESL instructors in the United Kingdom conducted by Burgess and Spencer (2000).

Because many ESL instructors have limited training and confidence in teaching pronunciation, it falls to general-skills textbooks to ensure that pronunciation is addressed in L2 classrooms. It is widely acknowledged that textbooks play a powerful role in many language classrooms (Bragger \& Rice, 2000; Chapelle, 2009). Bragger and Rice note that textbooks are used "for curriculum design, for lesson planning, as a basis for assessment, and perhaps too often, to define their [instructors'] approach to teaching" (p. 107). Several researchers have examined how various aspects of language are addressed in textbooks, including approaches to grammar (Aski, 2003; Fernández, 2011), cultural content (Chapelle; Gulliver, 2010), stylistic variation (Etienne \& Sax, 2009), pragmatics (Nguyen, 2011), and fluency (Rossiter et al., 2010). However, apart from examinations of pronunciation-specific materials (Gorsuch, 2001), little attention has been given to how pronunciation is treated in general ESL textbooks. Similarly, although there has been considerable discussion about textbook evaluation and selection (Ellis, 1997), little of this relates specifically to the teaching of pronunciation.

In the light of L2 pronunciation research, several criteria emerge for the effective incorporation of pronunciation into general-skills ESL textbooks. First, pronunciation activities and lessons should include both suprasegmental and segmental features (Derwing et al., 1998). When choosing which segments or minimal pairs to use, consideration should be given to how likely a minimal pair is to cause a communication breakdown. Textbooks should thus focus on vowels and consonants with high functional load. In an analy- 
sis of minimal pairs found in textbooks, Levis and Cortes (2008) identified several that were unlikely to cause communication breakdown either because the words were from different lexical categories (e.g., is/ease) or one of the words was highly infrequent; they give the example of think/sink, where the latter word rarely occurs in corpora of spoken English.

A variety of pronunciation task-types should also be included in L2 textbooks and preferably more than one type of task for each pronunciation feature being taught. A wide range of task types would benefit students of varied learning styles. Another important consideration is the inclusion of explicit explanations of pronunciation rules and features. Some aspects of pronunciation such as sentence level stress may not be salient to learners without clear explanations of what to listen for.

Changing one's pronunciation requires monitoring one's own speech and noticing errors, as well as making adjustments to productions in real time. The complexity of this task suggests that it is important for textbooks to review individual pronunciation features repeatedly and to link pronunciation to other language content for reinforcement.

In this study, we examine whether the L2 textbook industry has responded to students' desire for pronunciation instruction and whether research findings are reflected in the activities and topics in L2 general skills textbooks. Our research questions are as follows.

1. How much of the overall coverage in general skills ESL texts is devoted to pronunciation?

2. How consistent is the pronunciation coverage across various textbook series?

3. How do pronunciation foci and task types vary across textbook series?

4. To what extent do teachers' manuals provide support and background information about pronunciation activities?

\section{Method}

We surveyed 12 integrated-skills textbook series for pronunciation content (see Appendix A). All proficiency levels of students' books were surveyed for each series, as well as one instructors' manual from a subset of the series (48 texts and 6 manuals). Major publishers in Canada were asked to identify their most popular integrated skills texts (Oxford University Press, Pearson Education, Longman, Pearson Longman, Cambridge University Press). Other major publishers (Nelson, Prentice Hall, McGraw Hill) were also contacted, but their best sellers are not integrated-skills books. To keep comparisons consistent, such books were not included.

One of us went through each text page by page to identify the pronunciation activities. For each activity identified, an entry was recorded consisting of the page number and chapter, the number of lines, the general focus, and a brief description of the activity. A typical entry appears in Table 1. If a single 
Table 1

A Typical Spreadsheet Entry

\begin{tabular}{ll}
\hline Page number/Unit & 60,3 \\
\hline Number of lines & 8 \\
\hline Focus & word stress \\
\hline Description & 10 words, listen and place a stress marker on the stressed syllable \\
\hline
\end{tabular}

activity covered two aspects of pronunciation (e.g., an individual vowel and word stress in the same activity), it was counted as two activities. To ensure that entries were consistent, the original entries were reviewed and checked for accuracy and uniformity.

The focus entry initially consisted of categories created in advance. Examples of focus codes included word stress, intonation, vowels, and so forth. New topics encountered by the researcher were added to the focus list. If a textbook had a pronunciation section with more than one related activity, each activity was entered separately. For example, Interchange 1 included a pronunciation section with the vowel comparison of $/ \mathrm{ou} /$ and $/ \Lambda /$. There were two related activities. In activity A, learners heard six words with an /ou/ sound and six with a $/ \Lambda /$ sound. They were asked to "Listen to the difference and practice" (p. 109). In Activity B, learners listened to eight words and indicated which vowel they heard. These activities represented distinct tasks and were thus tabulated separately. Content and layout varied considerably from series to series. Ultimately, we chose to use an overestimate of a half-page for pronunciation activities because even a line count was somewhat arbitrary given the layout of some textbooks.

Because of the large number of entries, a computer program was developed to synthesize the data. The total numbers of entries was counted and the frequency of each topic tallied. Such information identified, for example, the topics covered most frequently and those that tended to be neglected.

To examine task types, including dictations, dialogues, and listen-and-repeat activities, a subset of five textbook series (22 books in all) was revisited (see Appendix B for task types). This information revealed trends in how texts orchestrated the process of learning pronunciation and indicated which tasks materials developers considered the most useful. 


\section{Results}

\section{Overall Coverage}

To gain a sense of the overall coverage of pronunciation topics (foci) in L2 textbooks, we examined the approximate percentage of each learner's textbook devoted to pronunciation activities or explanations. None of the books had instances of a half-page or more dedicated to individual pronunciation activities, so we estimated pronunciation content by calculating a half-page for each pronunciation entry compared with the overall number of pages in the book. The results of this overestimated calculation revealed a range of $0.4 \%$ to $15.1 \%$ across textbook series ( $M=5.0 \%$, see Appendix C).

We also examined the number of occurrences of each focus. Across all 48 textbooks, 28 foci occurred (see Appendix D for the full list). The suprasegmental features of intonation and sentence stress were most frequent (290 and 256 occurrences, respectively), with word stress (218), rhythm (182), and reductions (lexical variants such as hafta and gonna) (152) being the other most frequently covered prosodic features. Vowels were the segments most often addressed (136).

\section{Consistency Across Individual Series}

To determine how consistently each series covered pronunciation topics, we calculated the number of occurrences of pronunciation foci in each series and in individual books. American English File had a large number of pronunciation activities appearing consistently in all four textbooks in the series (102$152, M=128)$. Worldview also had consistently high numbers across the series (84-108, M=93). On the other hand, Passages and Canadian Concepts exhibited few pronunciation activities across the series ( 5 or fewer, with some books having none). The remaining series showed wide disparity in pronunciation emphasis. Workplace Plus, for example, had no pronunciation activities in the first three books, but in the fourth had 20. Top Notch Fundamentals had 108 pronunciation activities, whereas Top Notch Book 1 had only 50. Some textbooks in a series exhibited similar frequencies (e.g., Ventures ranged from 14 to 23); others such as the American Headway series (11-54) and the Touchstone series (38-51) showed greater variability in total coverage of pronunciation.

\section{Pronunciation Foci}

Table 2 demonstrates the numbers of pronunciation activities found in each series and the most commonly occurring foci. The range was broad, with American English File at 513 pronunciation activities, with word stress (96), vowels (87), rhythm (63), and sentence stress (51) being the most frequent, whereas Passages included only two pronunciation topics (word stress and sentence stress), with a total of only four activities. 
Table 2

Total Activities and Most Common Foci in Each Series

\begin{tabular}{|c|c|c|}
\hline Series & Total \# of activities & Most common foci \\
\hline American English File & 513 & $\begin{array}{l}\text { word stress (96) } \\
\text { vowels (87) } \\
\text { rhythm (63) } \\
\text { sentence stress (51) }\end{array}$ \\
\hline Worldview & 373 & $\begin{array}{l}\text { sentence stress (76) } \\
\text { word stress (55) } \\
\text { reductions (43) } \\
\text { linking (36) }\end{array}$ \\
\hline Top Notch & 261 & $\begin{array}{l}\text { intonation (113) } \\
\text { rhythm (104) } \\
\text { sentence stress (9) } \\
\text { phonetics (5) }\end{array}$ \\
\hline Touchstone & 181 & $\begin{array}{l}\text { intonation (41) } \\
\text { reductions (38) } \\
\text { sentence stress (36) } \\
\text { linking (26) }\end{array}$ \\
\hline Interchange & 137 & $\begin{array}{l}\text { reduction (27) } \\
\text { sentence stress (24) } \\
\text { intonation (20) } \\
\text { word stress (18) }\end{array}$ \\
\hline American Headway & 119 & $\begin{array}{l}\text { Sentence stress (31) } \\
\text { intonation (24) } \\
\text { word stress (15) } \\
\text { sound identification (11) }\end{array}$ \\
\hline Ventures & 103 & $\begin{array}{l}\text { sentence stress (17) } \\
\text { vowels (14) } \\
\text { word stress (12) } \\
\text { intonation (12) }\end{array}$ \\
\hline Step Forward Canada & 68 & $\begin{array}{l}\text { intonation (13) } \\
\text { syllables (12) } \\
\text { sound identification (8) } \\
\text { sentence stress }(7)\end{array}$ \\
\hline Side by Side & 54 & $\begin{array}{l}\text { reductions (25) } \\
\text { linking }(6) \\
\text { sentence stress (6) } \\
\text { intonation (5) }\end{array}$ \\
\hline Workplace Plus & 20 & intonation (20) \\
\hline
\end{tabular}


Table 2 (continued)

Total Activities and Most Common Foci in Each Series

\begin{tabular}{lll}
\hline Series & Total \# of activities & Most common foci \\
\hline Canadian Concepts & \multirow{2}{*}{11} & problem words (4) \\
& word stress (2) & -s endings (1) \\
& silent sounds (1) \\
& sounds and spelling (1) \\
& stress change (1) \\
& vowel (1) \\
& homographs (1) \\
& word stress (3) \\
Passages & sentence stress (1) \\
& 4 &
\end{tabular}

Priorities in each series varied. Some addressed certain pronunciation topics throughout the entire series, whereas others emphasized varied foci at varied proficiency levels. Worldview, for example, addressed 17 pronunciation foci across the series. Of these, 10 (clusters, contractions, intonation, linking, reductions, sentence stress, sound identification, stress change, vowels, and word stress) were addressed in every book. American English File addressed 23 foci across the series, but only 10 (clusters, consonants, linking, phonetics, rhythm, sentence stress, sound identification, sounds and spelling, vowels, and word stress) occurred in every book. Interchange had 16 foci, five of which (intonation, linking, reductions, sentence stress, and word stress) appeared in every book. Touchstone had 11 pronunciation foci, with four (intonation, linking, reductions, and sentence stress) occurring in every book. Step Forward Canada had 11 foci with four (intonation, sentence stress, sound identification, and word stress) occurring in both books in the series. The other textbooks covered varying numbers of topics, and in some instances individual books in the series contained no pronunciation activities at all. The topic totals across the other five series were American Headway (17), Canadian Concepts (7), Passages (2), Side by Side (9), Top Notch (20), Ventures (12), and Workplace Plus (1).

\section{Tasks and Task Types}

The range of tasks and task types were also examined for a subset of five popular series: American English File, Touchstone, Interchange, Side by Side, and Canadian Concepts. American English File and Canadian Concepts were chosen to represent the texts with the highest and lowest number of pronunciation activities respectively. The other three series were selected because they appeared to be representative of the pronunciation content in several series. 
Task types were grouped into 15 categories (see full list in Appendix B), including listen-and-repeat, controlled (i.e., scripted) conversations, explanations, sound discrimination, and dictations. Because the total number of task types for each textbook varied slightly from the number of foci and activities reported previously (some activities used more than one task type in a single section; e.g., a single entry in the original activity count could require students to classify and then listen and check), we report task types in percentages.

American English File used more varied task types than any other text, relying most heavily on classification (23\%), listen-and-repeat (19\%), controlled conversation (13\%), and listen-and-check (11\%). However, across the whole series only a single task was not scripted (free) and only $4 \%$ of tasks were partly scripted.

The most common task in Touchstone was noticing (30\%), where students were directed to listen to a sample and notice a certain aspect of pronunciation. This series had 25\% listen-and-repeat tasks and 14\% partly controlled tasks. There was a broad range of task-types (12). Touchstone had the highest number of free conversation tasks of any series (4\%). Pronunciation tasks were presented in one section per chapter, with each section containing two to four tasks.

The Interchange series, with 10 task types, used listen-and-repeat (32\%), noticing (19\%), controlled conversation (17\%), and explanations (12\%) most frequently. Although the number of controlled conversation tasks declined as the proficiency level of the series increased, there was no corresponding increase in partly controlled or free conversation tasks.

Side by Side used only four task types in the series; nearly $48 \%$ were listen-and-repeat, and 48\% were "say it, then listen." The other tasks were noticing (2), feature discrimination (1), and classify (1). Pronunciation information was presented in a single section at the end of every chapter.

In Canadian Concepts, only books 4, 5, and 6 had any pronunciation content. Of the foci activities covered, $58 \%$ were controlled conversation. There were three explanations, one listen-and-repeat task, and one classification task. The pronunciation tasks were not incorporated predictably.

\section{Integration of Pronunciation Activities Into Lessons}

We also examined how pronunciation topics were integrated into the subset of five series overall and how they were reinforced. One series, Canadian Concepts, did not address pronunciation topics in a standard format. The other series had a set format for laying out all topics, and pronunciation occupied a predictable, or at least a semi-regular, position in each chapter throughout. For these series, the pronunciation topic addressed in a section appeared to be closely related to a previous portion of the lesson, usually the grammar point preceding it. Pronunciation topics thus provided an opportunity to reinforce other language presented. For example, Unit four of Interchange 1 had 
a grammar activity on Yes/No and "Wh-questions with do" (p. 23). On the following page, the pronunciation section was on rising and falling intonation in yes/no questions. Only one of the students' textbook series regularly revisited a pronunciation topic after its initial presentation and practice (American English File). Rarely in the other series were pronunciation points revisited. Four of the series (American English File, Interchange, Side by Side, Touchstone) had a section after each chapter, or every few chapters, that provided a general review of the language covered to that point. Of these, only American English File reviewed some of the pronunciation topics deliberately. The other four series did not make a clear attempt to include pronunciation features in the review sections. Although there may have been incidental repetition, for most series, once a pronunciation topic had been addressed it was not revisited.

\section{Teachers' Manuals}

To answer research question 4 regarding teacher manuals' provision of support and background information for instructors, we surveyed one teacher manual where available for each of the series included in the subset above (American English File 3, Interchange Introduction, Side by Side 3, Touchstone 4). We also surveyed Topnotch 3 and Passages 2 (see Appendix E). We did not consider activities that appeared in the students' textbooks; rather, we looked for information unique to the teachers' text. The entries recorded for the manuals fell into three categories: new or supplementary activities, technical pronunciation information, and activities that reviewed pronunciation foci not included in the students' book. Some manuals provided general instructions to model pronunciation or to remind students to attend to their pronunciation while doing a task. Such nonspecific instructions were not included in the survey. Specific instructions such as to remind students to use reductions during the task were included.

The Top Notch 3 manual provided extra information for the teacher (65 entries). Of the 25 background information entries, 20 were dialogues for the corresponding listening task with marked sentence stress, intonation patterns, and pauses, indicating the patterns produced on a CD that accompanied the text. The matching entry in the students' book is a single line that says "rhythm and intonation practice" next to a headphones icon. It should be noted that although the teacher is provided with the correct prosodic information, the reasons for certain words being stressed or the significance of a given intonation pattern are not always indicated.

The Interchange manual had 51 entries, 15 of which were background information on pronunciation features, in addition to six activities in which the teacher was instructed to monitor special features (such as intonation) as the students performed a non-pronunciation task. The American English File presented 48 activities unique to the teachers' text; 23 provided background in- 
formation, 19 were extra activities, and five focused on review. In the Touchstone 4 manual, 13 of the 28 entries were supplementary with only five review activities in which the teacher was prompted to remind students to use informal lexical reductions or a particular intonation pattern in the speaking tasks. In the Side by Side 3 manual, each chapter included supplementary activities for 10 of the 25 pronunciation activities; however, only six entries provided background information for the teacher. Nine of the 25 entries were simply suggestions to model the specific pronunciation focus to be presented and to encourage students to practice the item. Of the 10 supplementary activities, most were discrimination tasks.

The Passages 2 teachers' manual had only one general instruction for the teacher to practice pronunciation of new words with the students. This was in keeping with the students' book, which incorporated little pronunciation.

\section{Discussion}

In answer to the first research question regarding the overall coverage devoted to pronunciation, we found notable disparities across texts and in series. For example, American English File included substantial numbers of activities in all levels in the series (over 100 in each case), whereas three other series had minimal pronunciation coverage. Although all the comprehensive skills series included some pronunciation activities, when choosing a class text, program directors and language instructors would be wise to consider carefully whether it meets the needs of their students.

In general, there was a heavier weighting toward suprasegmentals in the texts examined, but a broad range of segments was covered. Again, however, the balance and coverage of activities varied considerably from one series to another. Texts that made a concerted effort to include pronunciation with a range of task-types were the same ones that had a broader range of pronunciation foci and would thus better serve the needs of a class with mixed L1 backgrounds by providing instructors with a range of activities from which to select.

Several textbook writers have attended to research that indicates the importance of suprasegmentals to intelligibility and comprehensibility. Some of most common activities, with 276 occurrences, were related to sentence stress. This is promising, as Hahn (2004) has demonstrated that sentence stress plays an important role in intelligibility. Word stress was the third most common pronunciation focus, with 201 occurrences across the various series. This feature also has a significant effect on intelligibility (Field, 2005; Zielinski, 2008). One problem with the overall coverage of suprasegmentals is the fact that thought groups are poorly represented, but as an anonymous reviewer pointed out, it is difficult to teach intonation and sentence stress if thought groups have not already been introduced. Dickerson (2010) suggested that priorities in pronunciation instruction must be revisited to provide a more coherent picture for the students. 
Vowels were the sixth most common focus and the top segmental topic. This is also encouraging in the light of Zielinski's (2008) finding that vowels in stressed syllables are important to intelligibility. Although the other top foci (intonation, rhythm, and reductions such as hafta and gonna) have yet to be specifically examined in terms of their effect on intelligibility and comprehensibility, all three are reasonable choices for inclusion given their prominence in oral speech.

When we examined the consistency of pronunciation coverage across various series, we found marked disparities. American English File included over 100 activities in every book in the series, whereas only one of the books in the Workplace Plus series had any pronunciation activities at all. Canadian Concepts contained pronunciation activities in only three of its six levels, and even then there were only two to five activities per book. These differences across texts highlight the need for careful selection for programs. Even in a single series it is important to check for consistency. Some series (Worldview and American English File) are consistent across levels, but if a language program implements Top Notch across several class levels, learners at higher levels may be exposed to half as many pronunciation activities as learners in the first level.

Research question 3 asked "How do pronunciation foci and task-types vary across textbook series?" The findings indicate substantial differences. For example, Side by Side devoted nearly half all pronunciation activities to reductions (e.g., gonna) and approximately $80 \%$ of Top Notch's pronunciation activities were focused on intonation or rhythm. Although it is important to recycle pronunciation foci, one aspect of pronunciation should not be stressed to the exclusion of others that are potentially also important. This is particularly true in classes of mixed L1 backgrounds, where students may not share the same difficulties. Some textbooks have little in the way of segmental foci (see Appendix D). Although suprasegmentals are important, some learners have serious problems with high functional load segmental errors (e.g., p/b) and would benefit from attention to segments.

When examining foci in textbook series, it is important to consider the comprehensiveness and appropriateness of specific topics under an umbrella term such as sentence stress. For example, although intonation appears in the textbooks many times, the patterns presented tend to be limited. Intonation rules for yes/no versus information questions are common, as are rules for lists; however, few other specific uses of intonation are covered extensively. Notable exceptions include American English File 4, which has an activity in which learners listen to speakers and based on intonation, indicate who sounds more friendly and interested. Touchstone 4 explains how to use intonation to indicate whether a speaker is sure of a statement or is checking a fact. American Headway 4 includes an activity in which students have to listen to a conversation and determine whether the speakers know each other sim- 
ply by judging the intonation. Nonetheless, most intonation activities cover limited uses of intonation.

In the five series analyzed for task types, there were major differences in the types of activities. American English File, Interchange, and Touchstone all had 10 or more task types. Conversely, Side by Side focused heavily on two distinct task types despite a large number of individual tasks across the series. Using a variety of pronunciation tasks helps to ensure that learners with varied learning styles will benefit from the activities, as well as offering students who have difficulty more opportunities to achieve success. Apart from Canadian Concepts, which has very few pronunciation activities, listen and repeat is the task most consistently used across all the series analyzed. Although listen and repeat can encourage accurate perception and practice new aspects of pronunciation, it can be problematic if it is not tied to a clear pronunciation focus made explicit to the learners. In the absence of corrective feedback, it is possible that learners will "listen and repeat" a word or phrase without making changes to their productions. The pronunciation focus in the listen and repeat activities in the textbooks is usually indicated either through a sentence or title stating the focus, highlighting, or both. Little is provided in the way of explicit explanation of the target, and often there is only one task for a given focus. For example, in Side by Side, Book 4, there is a listen and repeat task with an informal reduction of the pronoun you as a focus. It is similar to all the listen and repeat activities in the book. The activity is labeled Reduced you and the instructions read, "Listen. Then say it" (p. 64). Three sentences are presented that contain the word you. Next to this are three more sentences, this time with the instruction, "Say it. Then listen." This isolated task seems unlikely to be of much help to learners who are not already familiar with how you is reduced in speech. It provides no information about when or how reduced you is typically used. Listen and repeat activities in the other texts were generally slightly better, but often suffered from similar problems. However, some textbooks did provide explanations and other tasks to support the language focus when using listen and repeat. In Interchange 2, learners were asked to listen to and repeat words with stress patterns marked above each syllable, then were asked to complete a follow-up task in which they listened to and categorized other words with the same stress patterns.

Other task types also varied in terms of quality. For example, noticing is a common task in three series. However, the stimuli provided for noticing activities tended to be short, with only a few words or sentences. In some cases noticing activities came with only a brief explanation and another short task such as listen and repeat as a supplement. Again, for learners who are unfamiliar with the pronunciation focus, this is unlikely to be helpful, particularly given the few opportunities to extend what they are learning to freer tasks. 
A serious problem with many tasks is the lack of clear, explicit explanations. With suprasegmentals in particular, it can be difficult for learners to know exactly what to listen for if pronunciation explanations are vague. The following quotes show the brevity of many of the explanations provided: "Remember, when people speak fast, they link words together" (American English File, Student Book 2, p. 23); "Notice how the stress changes to emphasize a contrast" (Interchange 2, p. 82); "Notice the reduction of "used to'" (Touchstone 3, p. 37). Although such superficial explanations can be problematic, they are superior to the substantial number of activities that have no explanations of the target focus at all.

Generally, the series with significant numbers of activities and task types also integrated the pronunciation activities into the larger lesson focus; however, many of the series gave little review. It is unclear how much explicit coverage an aspect of pronunciation requires to be learned, but vocabulary acquisition research indicates that for learners to acquire a new word through reading, several exposures are necessary (Rott, 1999). We are not suggesting that pronunciation and lexical acquisition are equivalent, but it is reasonable to assume that learners need several exposures to forms that they find difficult. All the series would benefit from additional review activities.

The teachers' manuals contained a range of supplementary activities: Top Notch included 65 entries different from the student text, whereas Passages 2 had only one direction to the teacher. In most instances, more explicit information about the nature of the pronunciation foci would provide teachers with a rationale for the activity and guidance to help them explain the activity to the students.

\section{Recommendations and Conclusion}

We were pleased to find that many general-skills textbook series include pronunciation activities, but in future editions we recommend that there be considerably more recycling of activities using a broad range of task types and including explicit explanations. We also suggest that textbook developers balance their inclusion of suprasegmental and segmental foci and that they take into consideration issues such as functional load. In addition, we recommend that textbooks make relatively even use of foci across texts in the same series, especially because some learners may use only a single text. Given the weight that a text can carry in an L2 classroom, it is essential that pronunciation receive adequate and integrated coverage if we are to respond better to the needs of L2 learners.

Because many teachers of English have limited or no formal training in teaching pronunciation (Foote et al., 2011) and that they have expressed discomfort teaching pronunciation (Burns, 2006), general-skills textbooks may be one of the few sources many L2 students have for pronunciation instruction. Many of the series reviewed here provide inadequate support to either 
the teacher or the learner, evidenced by a limited range of task types, few clear explanations in the students' texts and teachers' manuals, and limited review of pronunciation features covered. We see a need for more opportunities for professional development on the part of L2 teachers so that they will feel more comfortable and competent to introduce pronunciation activities. The current study suggests that improved integration of pronunciation in general-skills texts would benefit both teachers and students.

\section{Acknowledgments}

The authors thank Jun Deng for her assistance with the tabulation of some of the data presented here; Andrea Kushnir and Sarvenaz Hatami also provided help with checking the data for accuracy and consistency. We are grateful to Bruce Derwing for his careful reading of the article. We appreciate the comments of two anonymous reviewers who provided useful input. This work was supported by the Social Sciences and Humanities Research Council of Canada (SRG 410-2010-0151+); a Support for the Advancement of Scholarship grant, Faculty of Education, University of Alberta; a grant from the Office of the Vice-President, Research, University of Alberta; and a grant from the Faculty of Education, University of Alberta.

\section{The Authors}

Tracey Derwing is a professor of TESL in the Department of Educational Psychology at the University of Alberta. Her primary research interests include the development of L2 oral language skills, including pronunciation, fluency, and pragmatics. She is also interested in immigration policy.

Lori Diepenbroek is an ESL instructor at MacEwan University in Edmonton. She obtained a master's in TESL at the University of Alberta in 2009. Lori is interested in the practice of pronunciation and pragmatics instruction in ESL classes.

Jennifer Foote is a doctoral student at Concordia University in Montreal. She received her MEd in TESL at the University of Alberta. She has also worked for several years as an ESL/EFL instructor. Her research interests include pedagogical approaches to teaching pronunciation and speech perception.

\section{References}

Anderson-Hsieh, J., Johnson, R., \& Koehler, K. (1992). The relationship between native speaker judgements of nonnative pronunciation and deviance in segmentals, prosody, and syllable structure. Language Learning, 42, 529-555.

Aski, J.M. (2003). Foreign language textbook activities: Keeping pace with second language acquisition research. Foreign Language Annals, 36(1), 57-65.

Bragger, J.D., \& Rice, D.B. (2000). Foreign language materials: Yesterday, today, and tomorrow. In R.M. Terry (Ed.), Agents of change in a changing age (pp. 107-140). Lincolnwood, IL: National Textbook Company.

Burgess, J., \& Spencer, S. (2000). Phonology and pronunciation in integrated language teaching and teacher education. System, 28, 191-215.

Burns, A. (2006). Integrating research and professional development on pronunciation teaching in a national adult ESL program. TESL Reporter, 39(2), 34-41.

Catford, J.C. (1987). Phonetics and the teaching of pronunciation: A systemic description of English phonology. In J. Morley (Ed.), Current perspectives on pronunciation: Practices anchored in theory (pp. 87-100). Washington, DC: TESOL. 
Celce-Murcia, M., Brinton, D.M., Goodwin, J.M., with Griner, B. (2010). Teaching pronunciation: A course book and reference guide (2nd ed.). New York: Cambridge University Press.

Chapelle, C.A. (2009). A hidden curriculum in language textbooks: Are beginning learners of French at U.S. universities taught about Canada? Modern Language Journal, 93, 139-152.

Couper, G. (2003). The value of an explicit pronunciation syllabus in ESOL teaching. Prospect, 18(3), 53-70. Available:

http://www.ameprc.mq.edu.au/docs/prospect_journal/volume_18_no_3/18_3_4_Couper.pdf

Couper, G. (2006). The short and long-term effects of pronunciation instruction. Prospect, 21(1), 46-66. Available:

http://www.ameprc.mq.edu.au/docs/prospect_journal/volume_21_no_1/21_1_3_Couper.pdf

Davila, A., Bohara, A.K., \& Saenz, R. (1993). Accent penalties and the earnings of Mexican Americans. Social Science Quarterly, 74, 902-916.

Derwing, T.M., \& Munro, M.J. (2005). Second language accent and pronunciation teaching: A research-based approach. TESOL Quarterly, 39(3), 379-397.

Derwing, T.M., Munro, M.J., \& Wiebe, G.E. (1998). Evidence in favour of a broad framework for pronunciation instruction. Language Learning, 48, 393-410.

Derwing, T.M., \& Rossiter, M.J. (2002). ESL learners' perceptions of their pronunciation needs and strategies. System, 30, 155-166.

Dickerson, W.B. (2010). Walking the walk: Integrating the story of English phonology. In J. Levis \& K. LeVelle (Eds.), Proceedings from the 1st Conference of Pronunciation in Second Language Learning and Teaching (pp. 10-23). Ames, IA: Iowa State University.

Ellis, R. (1997). The empirical evaluation of language teaching materials. ELT Journal, 51(1), 3642.

Etienne, C., \& Sax, K. (2009). Stylistic variation in French: Bridging the gap between research and textbooks. Modern Language Journal, 93, 584-606.

Fernández, C. (2011). Approaches to grammar instruction in teaching materials: A study in current L2 beginning-level Spanish textbooks. Hispania, 94(1), 155-170. Available: http://muse.jhu.edu/journals/hispania/v094/94.1.fernandez.html

Field, J. (2005). Intelligibility and the listener: The role of lexical stress. TESOL Quarterly, 39, 399-423.

Foote, J.A., Holtby, A.I., \& Derwing, T.M. (2011a). Survey of ESL teachers' pronunciation practices. Unpublished data.

Foote, J.A., Holtby, A.K., \& Derwing, T.M. (2011b). Survey of the teaching of pronunciation in adult ESL programs in Canada, 2010. TESL Canada Journal, 29, 1-22. Available: http://www.teslcanadajournal.ca/index.php/tesl/article/viewFile/1086/905

Gilbert, J.B. (2004). Clear speech: Pronunciation and listening comprehension in North American English (3rd ed.). New York: Cambridge University Press.

Gorsuch, G.J. (2001). Testing textbook theories and tests: The case of suprasegmentals in a pronunciation textbook. System, 29, 119-136.

Grant, L. (2010). Well said: Pronunciation for clear communication (3rd ed.). Boston, MA: Heinle \& Heinle.

Gulliver, T. (2010). Immigrant success stories in ESL textbooks. TESOL Quarterly, 44, 725-745.

Hahn, L.D. (2004). Primary stress and intelligibility: Research to motivate the teaching of suprasegmentals. TESOL Quarterly, 38, 201-223.

Hewings, M. (2004). Pronunciation practice activities: A resource book for teaching English pronunciation. Cambridge, UK: Cambridge University Press.

Isaacs, T. (2008). Towards defining a valid assessment criterion of pronunciation proficiency in non-native English-speaking graduate students. Canadian Modern Language Review, 64, 555-580.

Isaacs, T. (2009). Integrating form and meaning in L2 pronunciation instruction. TESL Canada Journal, 27, 1-12. Available:

http://www.teslcanadajournal.ca/index.php/tesl/article/viewFile/1034/853 
Kennedy, S., \& Trofimovich, P. (2008). Intelligibility, comprehensibility, and accentedness of L2 speech: The role of listener experience and semantic context. Canadian Modern Language Review, 64, 459-489.

Levis, J. (2005). Changing contexts and shifting paradigms in pronunciation teaching. TESOL Quarterly, 39, 369-377.

Levis, J., \& Cortes, V. (2008). Minimal pairs in spoken corpora: Implications for pronunciation assessment and teaching. In C.A. Chapelle, Y.-R. Chung, \& J. Xu (Eds.), Towards adaptive CALL: Natural language processing for diagnostic language assessment (pp. 197-208). Ames, IA: Iowa State University.

Munro, M.J., \& Derwing, T.M. (1995a). Foreign accent, comprehensibility, and intelligibility in the speech of second language learners. Language Learning, 45(1), 73-97.

Munro, M.J., \& Derwing, T.M. (1995b). Processing time, accent, and comprehensibility in the perception of native and foreign accented speech. Language and Speech, 38, 289-306.

Munro, M.J., \& Derwing, T.M. (2001). Modeling perceptions of the accentedness and comprehensibility of L2 speech: The role of speaking rate. Studies in Second Language Acquisition, 23, 451-468.

Munro, M.J., \& Derwing, T.M. (2006). The functional load principle in ESL pronunciation instruction: An exploratory study. System, 34, 520-531.

Nguyen, M.T.T. (2011). Learning to communicate in a globalized world: To what extent do school textbooks facilitate the development of intercultural pragmatic competence? RELC Journal, 42(1), 17-30.

Pendakur, K., \& Pendakur, R. (1997). Speak and ye shall receive: Language knowledge as human capital (WP \#97-10). Vancouver, BC: Research on Immigration and Integration in the Metropolis.

Reitz, J.G., \& Sklar, S.M. (1997). Culture, race, and the economic assimilation of immigrants. Sociological Forum, 12, 233-277.

Rossiter, M.J., Derwing, T.M., Manimtim, L.G., \& Thomson, R.I. (2010). Oral fluency: The neglected component in the communicative language classroom. Canadian Modern Language Review, 66, 583-606.

Rott, S. (1999). The effect of exposure frequency on intermediate language learners' incidental vocabulary acquisition and retention through reading. Studies in Second Language Acquisition, 21, 589-619.

Saito, K., \& Lyster, R. (2012). Effects of form-focused instruction and corrective feedback on L2 pronunciation development of / $/$ / by Japanese learners of English. Language Learning, 62, 595-633.

Yates, L., \& Zielinski, B. (2009). Give it a go: Teaching pronunciation to adults. Sydney, NSW: AMEP Research Centre. Available: http://www.ameprc.mq.edu.au/_data/assets/pdf_file/0011/157664/interactive_sm.pdf

Zielinski, B.W. (2008). The listener: No longer the silent partner in reduced intelligibility. System, 36, 69-84. 


\section{Textbooks and Teacher Manuals Surveyed}

Berish, L., \& Thibaudeau, S. (1997). Canadian concepts 1, 2, 3, 4, 5, \& 6 (2nd ed.). Don Mills, ON: Pearson Education.

Bitterlin, G., Johnson, D., Price, D., Ramirez, S., \& Savage, K.L. (2008). Ventures basic, 1, 2, 3, \& 4. White Plains, NY: Cambridge University Press.

McCarthy, M., MacCarten, J., \& Sandiford, H. (2005). Touchstone 1 \& 2. Cambridge, UK: Cambridge University Press.

McCarthy, M., MacCarten, J., \& Sandiford, H. (2006). Touchstone 3, 4, \& teacher's edition 4. Cambridge, UK: Cambridge University Press.

Molinsky, S.J., \& Bliss, B. (2001). Side by side 1 \& 2 (3rd ed.). White Plains, NY: Pearson Longman.

Molinsky, S.J., \& Bliss, B. (2002). Side by side 3 \& teacher's guide 3 (3rd ed.). White Plains, NY: Pearson Longman.

Molinsky, S.J., \& Bliss, B. (2003). Side by side 4 (3rd ed.). White Plains, NY: Pearson Longman.

Oxenden, C., Latham-Koenig, C., \& Seligson, P. (2008). American English file 1 \& 2. New York: Oxford University Press.

Oxenden, C., Latham-Koenig, C., \& Seligson, P. (2008). American English file 3: Teacher's book. New York: Oxford University Press.

Oxenden, C., Latham-Koenig, C., \& Seligson, P. (2009). American English file 3 \& 4. New York: Oxford University Press.

Rajabi, S., \& Spigarelli, J. (2008). Step forward Canada 1. Don Mills, ON: Oxford University Press.

Rajabi, S., \& Wisniewska, I. (2008). Step forward Canada 2. Don Mills, ON: Oxford University Press.

Richards, J.C. (2005). Interchange intro, intro teacher's edition, 1, 2, \& 3 (3rd ed.). New York: Cambridge University Press.

Richards, J.C., \& Sandy, C. (2008). Passages 1, 2, E teacher's manual 2 (2nd ed.). New York: Cambridge University Press.

Rost, M., le Maistre, S., Lewis, C., \& Sharpe, K. (2005). WorldView 1, 2, 3, \& 4. White Plains, NY: Pearson Longman.

Saslow, J., \& Ascher, A. (2006). Top notch fundamentals, 1, 2, 3, \& teacher's edition and lesson planner 3. White Plains, NY: Pearson Longman.

Saslow, J. (2001). Workplace plus: Living and working in English 1. White Plains, NY: Pearson Longman.

Saslow, J. (2002). Workplace plus: Living and working in English 2 \& 3. White Plains, NY: Pearson Longman.

Saslow, J. (2003). Workplace plus: Living and working in English 4. White Plains, NY: Pearson Longman.

Soars, L., \& Soars, J. (2001). American headway 1 \& 2. New York: Oxford University Press. Soars, L., \& Soars, J. (2002). American headway starter. New York: Oxford University Press. Soars, L., \& Soars, J. (2003). American headway 3. New York: Oxford University Press.

Soars, L., \& Soars, J. (2005). American headway 4. New York: Oxford University Press. 
Appendix A

Number of Pronunciation Activities in Texts

\begin{tabular}{|c|c|c|c|}
\hline Name of Textbook & $\begin{array}{c}\text { Pron. } \\
\text { Activities }\end{array}$ & Name of Textbook & $\begin{array}{c}\text { Pron. } \\
\text { Activities }\end{array}$ \\
\hline American English File 1 & 152 & Step Forward Canada 1 & 31 \\
\hline American English File 2 & 149 & Step Forward Canada 2 & 37 \\
\hline American English File 3 & 102 & & \\
\hline \multirow[t]{2}{*}{ American English File 4} & 110 & Top Notch Fundamentals & 108 \\
\hline & & Top Notch 1 & 50 \\
\hline American Headway Starter & 16 & Top Notch 2 & 51 \\
\hline American Headway 1 & 25 & Top Notch 3 & 52 \\
\hline American Headway 2 & 11 & & \\
\hline American Headway 3 & 13 & Touchstone 1 & 51 \\
\hline \multirow[t]{2}{*}{ American Headway 4} & 54 & Touchstone 2 & 45 \\
\hline & & Touchstone 3 & 44 \\
\hline Canadian Concepts 1 & 0 & Touchstone 4 & 38 \\
\hline Canadian Concepts 2 & 0 & & \\
\hline Canadian Concepts 3 & 0 & Ventures Basic & 14 \\
\hline Canadian Concepts 4 & 2 & Ventures 1 & 21 \\
\hline Canadian Concepts 5 & 5 & Ventures 2 & 22 \\
\hline \multirow[t]{2}{*}{ Canadian Concepts 6} & 4 & Ventures 3 & 23 \\
\hline & & Ventures 4 & 23 \\
\hline Interchange Intro & 36 & & \\
\hline Interchange 1 & 30 & Workplace Plus 1 & 0 \\
\hline Interchange 2 & 37 & Workplace Plus 2 & 0 \\
\hline \multirow[t]{2}{*}{ Interchange 3} & 34 & Workplace Plus 3 & 0 \\
\hline & & Workplace Plus 4 & 20 \\
\hline Passages 1 & 2 & & \\
\hline \multirow[t]{2}{*}{ Passages 2} & 2 & Worldview 1 & 84 \\
\hline & & Worldview 2 & 94 \\
\hline Side by Side 1 & 20 & Worldview 3 & 108 \\
\hline Side by Side 2 & 14 & Worldview 4 & 87 \\
\hline Side by Side 3 & 10 & & \\
\hline Side by Side 4 & 10 & & \\
\hline
\end{tabular}


Appendix B

Pronunciation Task Types

\begin{tabular}{lc}
\hline Task type & Task percentage \\
\hline Listen and repeat & 25.0 \\
Classify & 13.0 \\
Noticing (stand-alone) & 12.1 \\
Controlled conversation & 11.2 \\
Listen and check & 11.0 \\
Explanation & 10.3 \\
Sound discrimination & 5.8 \\
Partly controlled conversation & 5.4 \\
Phonetics & 2.2 \\
Dictation & 2.1 \\
Free conversation & 1.3 \\
Reporting & 0.3 \\
Monologue & 0.2 \\
Test & 0.2 \\
Listen only & 0.1 \\
\hline
\end{tabular}


Appendix C

Percentage of Textbook Series Dedicated to Pronunciation

\begin{tabular}{lc}
\hline Series & Percentage \\
\hline American English File & 15.1 \\
Top Notch & 11.1 \\
Worldview & 9.0 \\
Interchange & 5.6 \\
Touchstone & 4.1 \\
Side by Side & 4.1 \\
American Headway & 3.6 \\
Step Forward Canada & 2.8 \\
Ventures & 1.5 \\
Workplace Plus & 1.5 \\
Passages & 0.7 \\
Canadian Concepts & 0.4 \\
\hline Mean & 5.0 \\
\hline
\end{tabular}


Appendix D

Total Occurrences of Pronunciation Foci

\begin{tabular}{llll}
\hline Focus & Frequency & Focus & Frequency \\
\hline Intonation & 290 & Phonetics & 30 \\
Sentence stress & 276 & Sounds \& spelling & 27 \\
Word stress & 201 & Schwa & 21 \\
Rhythm & 182 & Deletion & 20 \\
Reductions & 152 & Silent sounds & 19 \\
Vowels & 136 & Thought groups & 17 \\
Linking & 90 & Numbers & 12 \\
Sound identification & 76 & Alphabet & 9 \\
Clusters & 54 & Rhyme & 8 \\
-s endings & 44 & Problem words & 8 \\
-ed endings & 43 & Dictionary & 6 \\
Syllables & 41 & Homophones & 4 \\
Consonants & 38 & Others & 2 \\
Contractions & 37 & Homographs & 1 \\
\hline
\end{tabular}

Appendix $\mathrm{E}$

Occurrences of Foci in Teachers' Manuals

\begin{tabular}{lc}
\hline Name & Total Entries \\
\hline American English File 3 & 48 \\
Interchange Intro & 51 \\
Passages 2 & 1 \\
Side by Side 3 & 25 \\
Top Notch 3 & 65 \\
Touchstone 4 & 28 \\
\hline
\end{tabular}

